\title{
Wpływ kompatybilności rop na depozycję osadów w łańcuchu dystrybucji ropy naftowej
}

\section{The effect of oil compatibility on sediments deposition in the crude oil distribution chain}

\author{
Sławomir Szuflita, Wojciech Krasodomski, Jerzy Kuśnierczyk, Mirosław Wojnicki, Marcin Warnecki \\ Instytut Nafty i Gazu - Państwowy Instytut Badawczy
}

\begin{abstract}
STRESZCZENIE: Z danych Eurostatu wynika, że w w pierwszej połowie 2019 r. import ropy do Polski wyniósł 12,7 mln ton ropy, z czego 63\% stanowiły dostawy z Rosji, podczas gdy jeszcze w 2013 r. było to aż 95\%. Przy dążeniu do większego bezpieczeństwa energetycznego koncerny naftowe skłaniają się do pozyskiwania ropy naftowej z różnych źródeł, przez co istnieje silna potrzeba zintensyfikowania prac nad tematyką badań mieszalności różnych typów rop pod kątem wytrącania się osadów. Mieszanie rop dostarczanych z różnych źródeł generuje dodatkowy problem pojawiający się trakcie przetwarzania rop w rafinerii, a mianowicie ich kompatybilność. Ropy naftowe pochodzące z różnych źródeł potrafią diametralnie różnić się właściwościami fizykochemicznymi oraz składem grupowym, co determinuje konieczność odpowiedniego postępowania celem bezproblemowej pracy rafinerii z mieszaninami różnych gatunków. Problem niekompatybilności rop dotyczy przede wszystkim sytuacji, gdy wśród mieszanych rop jedna jest ropą wysokoparafinową, z natury zawierającą niewielką ilość asfaltenów, a inna ropą o niewielkiej zawartości węglowodorów nasyconych, za to o większej zawartości żywic i asfaltenów. Obie te ropy osobno mogą być całkowicie stabilne i nie powodować problemów z osadami asfaltenowymi, jednak ich mieszanie może skutkować pojawieniem się tychże osadów. W artykule przedstawiono autorską metodykę filtrowania w warunkach uwzględniających ciśnienie i temperaturę, jaka panują w trakcie procesu przeróbki ropy. Dodatkowo, wykorzystując odpowiednio skonstruowany układ filtrujący, określono ilość odseparowanego osadu dla czystych próbek rop, jak i ich mieszanin w różnych proporcjach. Filtrowanie rop i ich mieszanin wykonano w dwóch temperaturach: $20^{\circ} \mathrm{C}$ i $150^{\circ} \mathrm{C}$ pod ciśnieniem 20 bar. Badania kompatybilności rop przeprowadzono dla trzech rop, różniących się nie tylko kierunkiem dostawy, ale również składem i parametrami.
\end{abstract}

Słowa kluczowe: asfalteny, parafiny, filtrowanie.

ABSTRACT: According to Eurostat data, oil imports to Poland in the first half of 2019 amounted to 12.7 million tonnes of oil, of which $63 \%$ were supplied from Russia, wherein 2013 it was as much as $95 \%$. In pursuit of greater energy security, oil companies are encouraged to acquire crude oil from various sources, which is the reason for the intensification of research on sedimentation caused by blending different types of crude oils. Mixing of crude oils supplied from different sources generates an additional issue accompanying processing of crude oils in the refinery, namely its compatibility. Crude oils from different sources can differ significantly in terms of physical and chemical properties and fractional composition, which determines the need for proper processing in the refinery to maintain the continuity of uninterrupted operations with different oil blends. The problem of incompatibility of crude oil is related mainly to the situation when one of the blended crude oils is a high-paraffin type containing a small amount of asphaltenes, and the second one has a low content of saturated hydrocarbons, but a higher content of resins and asphaltenes. These two are completely stable alone and would not cause problems with asphaltene sediments, but blending them could result in the formation of such sediments. The paper describes an original method of crude oil filtering taking into account the pressure and temperature conditions related to oil processing in the refinery. Moreover, using a properly designed filtering system, it was possible to determine the amount of sediment for pure oils as well as their blends in different proportions. Filtering of crude oil and its mixtures was performed at two temperatures of $20^{\circ} \mathrm{C}$ and $150^{\circ} \mathrm{C}$, at pressure conditions of 20 bar. Crude oil compatibility tests were conducted for three oils differing in the source, composition and physical properties.

Key words: paraffins, asphaltenes, filtration.

Autor do korespondencji: S. Szuflita, e-mail: slawomir.szuflita@inig.pl

Artykuł nadesłano do Redakcji: 17.12.2019 r. Zatwierdzono do druku: 22.08.2020 r. 


\section{Wstęp}

Przetwórstwo ropy naftowej na świecie odbywa się w sposób ciągły, a w rafineriach co roku przerabia się ok. $450 \mathrm{mln}$ ton ropy. Wraz z rozwojem gospodarczym stale wzrasta popyt na produkty węglowodorowe, dlatego większość rafinerii pracuje z maksymalną mocą produkcyjną. W takiej sytuacji każdorazowy przypadek, w którym zachodzi konieczność przerwy serwisowej pracującej instalacji, jest niezwykle kosztowny. Wielkocząsteczkowe węglowodory aromatyczne będące składnikami ropy naftowej mają silną tendencję do akumulacji i osadzania się na wymiennikach ciepła, ścianach reaktora, zbiornikach magazynowych, a także na katalizatorach. Może to spowodować konieczność częstego wyłączania jednostki na czas zaplanowanego bądź - co gorsza - nieplanowanego czyszczenia. Ponadto osady te izolują powierzchnie zaprojektowane do przenoszenia ciepła i skutkują jego stratami, co znacznie podnosi koszty operacyjne. Otwarty rynek i kwestie bezpieczeństwa energetycznego skłaniają koncerny naftowe do pozyskiwania ropy naftowej z różnych źródeł, przez co istnieje silna potrzeba zintensyfikowania prac nad tematyką badań kompatybilności różnych typów rop pod kątem wytrącania się osadów.

\section{Analiza teoretyczna}

\section{Fizyczny model ropy naftowej}

Przemiany fazowe ropy naftowej są skomplikowane ze względu na dużą liczbę różnorodnych cząsteczek tworzących mieszaninę oraz dlatego, że wykazuje ona właściwości zarówno układu koloidalnego, jak i roztworu (Wiehe i Kennedy, 2000). Ropę, w której skład wchodzi ponad milion różnych cząstek, klasyfikuje się w czterech typach: asfaltenów (A), aromatów (a), węglowodorów nasyconych (s) i żywic (R) (Pfeiffer i Saal, 1940). Na rysunku 1 przedstawiono przybliżony model fizyczny ropy naftowej.

\section{S S S \\ $\mathrm{S}$ a a a $\mathrm{S}$ \\ $s$ a R R R a $s$ \\ $s$ a $\mathrm{A} A \mathrm{R}$ a s \\ $s$ a $\mathrm{A} A \mathrm{~A}$ a s \\ $s$ a R R R a \\ $\mathrm{s}$ a a a s \\ S S S}

Rys. 1. Przybliżony model ropy naftowej (Wiehe i Kennedy, 2000): A - asfalteny (substancja rozpuszczona); R - żywice (dyspersant); a - aromaty (rozpuszczalnik); $\mathrm{s}$ - węglowodory nasycone (nierozpuszczalnik)

Fig. 1. Approximate model of crude oil (Wiehe i Kennedy, 2000): A - Asphaltenes; R - Resins; a - Aromatic; s - Saturated
W ropie naftowej asfalteny pozostają w równowadze fazowej, która może zostać łatwo zaburzona poprzez zwiększenie udziału węglowodorów nasyconych lub zmniejszenie ilości żywic lub aromatów (Wiehe, 2008).

Mieszanie różnych typów ropy naftowej może znacząco zmienić zawartość tych składników w ostatecznej mieszaninie, co doprowadzi do zaburzenia równowagi i wytrącenia asfaltenów.

\section{Wtaściwości asfaltenów}

Asfalteny są makrocząsteczkami zbudowanymi z aromatycznego „rdzenia” zawierającego heteroatomy (tlenu, azotu lub siarki) i z łańcuchów alifatycznych. Są one zazwyczaj definiowane jako frakcja nierozpuszczalna w węglowodorach nasyconych, np. n-heptan, rozpuszczalna częściowo natomiast w węglowodorach aromatycznych, takich jak np. toluen. Nawet w niewielkich koncentracjach cząsteczki asfaltenów mają tendencję do agregowania i flokulacji, będąc źródłem poważnych zagrożeń podczas wydobycia i przetwarzania ropy naftowej (Lubaś et al., 2012).

Przyczyny nierozpuszczalności asfaltenów to (Wiehe, 2008; Painter et al., 2015):

- wiązania wodorowe lub inne interakcje donor-akceptor;

- duża masa cząsteczkowa;

- polarność.

\section{Badania stabilności ropy naftowej}

Jak już wcześniej wspomniano, mieszanie rop pochodzących z różnych kierunków prowadzi do przemian chemicznych asfaltenów, co może skutkować poważnymi problemami technologicznymi. Dlatego też badania nad stabilnością ropy i sposobami przewidywania flokulacji i wytrącania asfaltenów objęte są szczególnym zainteresowaniem czołowych firm naftowych.

Niektóre metody szacowania zagrożenia wytrącaniem osadów opierają się jedynie na analizie składów ropy naftowej. Nie pozwalają one jednak na pełne określenie stabilności, gdyż precypitacja nie jest zależna jedynie od składu, ale również od fizykochemicznych właściwości fazy ciągłej i rozproszonej oraz od warunków ciśnienia i temperatury (Hirschberg et al., 1984; Carbognani et al., 1999; Rogel i Carbognani, 2003). Mieszaniny różnych typów rop naftowych mogą mieć mniejszą stabilność niż ropy macierzyste na skutek zachodzących interakcji i destabilizacji poszczególnych frakcji (Wiehe et al., 2001). Poniżej przedstawiono dostępne w literaturze metody laboratoryjne i empiryczne określania stabilności ropy naftowej: - wskaźnik niestabilności koloidalnej (colloidal instability index - CII) (Wiehe i Kennedy, 2000);

- wskaźnik stabilności koloidalnej (colloidal stability indexCSI) (Goual i Firoozabadi, 2002; Rogel i Carbognani, 2003); 
- wskaźnik stabilności (z ang. stability index) (Asomaning i Watkinson, 2000);

- wykres Stankiewicza (Stankiewicz et al., 2002);

- parametr stabilności Sepúlvedy - analiza jakościowoilościowa (qualitative-quantitative analysis - QQA) (Sepúlveda et al., 2010);

- parametr stabilności Sepúlvedy - krzyżowy wykres stabilności (stability cross plot - SCP) (Sepúlveda et al., 2010).

\section{Laboratoryjne badania kompatybilności ropy naftowej}

Analiza SARA (Wang i Buckley, 2003; ASTM D5186)

Określenie początku wytrącania asfaltenów (onset of asphaltene precipitation - OAP) (Warnecki, 2011).

\section{Analiza wartości P (P-value)}

Badanie to jest oparte na metodzie ASTM D-7112 i wykorzystuje analizator stabilności i kompatybilności ropy naftowej Porla. Stabilność i kompatybilność są określane na podstawie analizy strąceniowej (n-heptan) i detekcji optycznej w trzech różnych roztworach ksylenu. Roztwór jest przepuszczany przez detektor optyczny, który wykrywa wytrącanie się asfaltenów, analizując rozproszenie światła.

\section{Analiza wartości S (S-value)}

Badanie to jest oparte na metodzie ASTM D-7112 i wykorzystuje automatyczny analizator stabilności ROFA France, wyposażony w optyczny czujnik wykrywający wytrącanie się asfaltenów z trzech różnych próbek ropy naftowej rozpuszczonej w toluenie. Wykonywane jest automatyczne miareczkowanie przy użyciu n-heptanu do momentu wytrącenia się asfaltenów. Następnie rejestrowane są zmiany w natężeniu światła zachodzące podczas flokulacji asfaltenów. Na tej podstawie obliczane są parametry stabilności ropy.

Pomiar separacji fazowej indukowanej n-heptanem z wykorzystaniem skanera optycznego

Badanie to, oparte na metodzie ASTM D-7061, pozwala na określenie kompatybilności ropy naftowej na podstawie pomiaru transmitancji lub rozpraszania światła w trakcie flokulacji asfaltenów (Guzmán et al., 2017).

\section{Statyczny test stabilności}

Stabilność ropy naftowej może być określona na podstawie prostego statycznego testu stabilności:

- pomiar początkowych parametrów próbki ropy w warunkach pokojowych $\left(P_{0}\right)$;

- przechowywanie próbki ropy w pojemniku ciśnieniowym, w określonych warunkach ciśnienia i temperatury (odpowiadających np. rzeczywistym warunkom magazynowania ropy), przez określony czas (co najmniej 15 dni);

- pobór próbki ropy z dna pojemnika i ponowne określenie parametrów $\left(P_{f}\right)$.

Wskaźnik stabilności $=\frac{P_{f}}{P_{0}}$

gdzie: $P_{0}$ jest to wartość danego parametru próbki na początku eksperymentu, a $P_{f}$ - na końcu eksperymentu. Najwyższa wartość wskaźnika stabilności wynosi 1, gdy właściwości ropy są niezmienne w czasie. Najczęściej stosowanym parametrem w teście jest zawartość osadu asfaltenowego (Guzmán et al., 2017).

\section{Test punktowy}

Jest to prosty test wykorzystywany do wykrywania ewentualnej niekompatybilności rop naftowych ze względu na różnice w ich charakterze. Jedna kropla danej mieszaniny jest umieszczana na papierze filtracyjnym. Po wysuszeniu jest ona klasyfikowana wizualnie do następujących typów (ASTM D4740-19):

1. homogeniczny punkt bez wewnętrznego pierścienia;

2. niewyraźny lub słabo zaznaczony pierścień wewnętrzny;

3. dobrze zaznaczony, cienki pierścień wewnętrzny, delikatnie ciemniejszy od tła;

4. wyraźny i gruby pierścień wewnętrzny, zdecydowanie ciemniejszy od tła;

5. bardzo ciemna, pokryta widoczną warstwą ciała stałego powierzchnia w centrum punktu. Tło zdecydowanie jaśniejsze.

\section{Metodyka badań}

Do badań kompatybilności rop handlowych użyto trzech różniących się od siebie rop. Do filtrowania wykorzystano specjalistyczny filtr specjalnie przystosowany do tego typu badań. Zestaw filtrujący wyposażony został w dwa rodzaje filtrów używanych w zależności od temperatury, w jakiej odbywało się filtrowanie.

Parametry filtrów użytych do badań:

- filtrowanie w temperaturze $20^{\circ} \mathrm{C}$ - filtr $2,7 \mu \mathrm{m}$;

- filtrowanie $\mathrm{w}$ temperaturze $150^{\circ} \mathrm{C}-$ filtr $0,8 \mu \mathrm{m}$.

\section{Opis aparatury oraz metodyka filtrowania rop i ich mieszanin}

Badania kompatybilności różnych rop prowadzono z wykorzystaniem bezrtęciowej aparatury PVT do badań właściwości fazowych płynów złożowych (rys. 2).

Przedstawioną na rysunku 2 aparaturę wykorzystano do badań kompatybilności rop i ich mieszanin w różnych temperaturach. Dla realizacji tych badań zestaw PVT został odpowiednio 


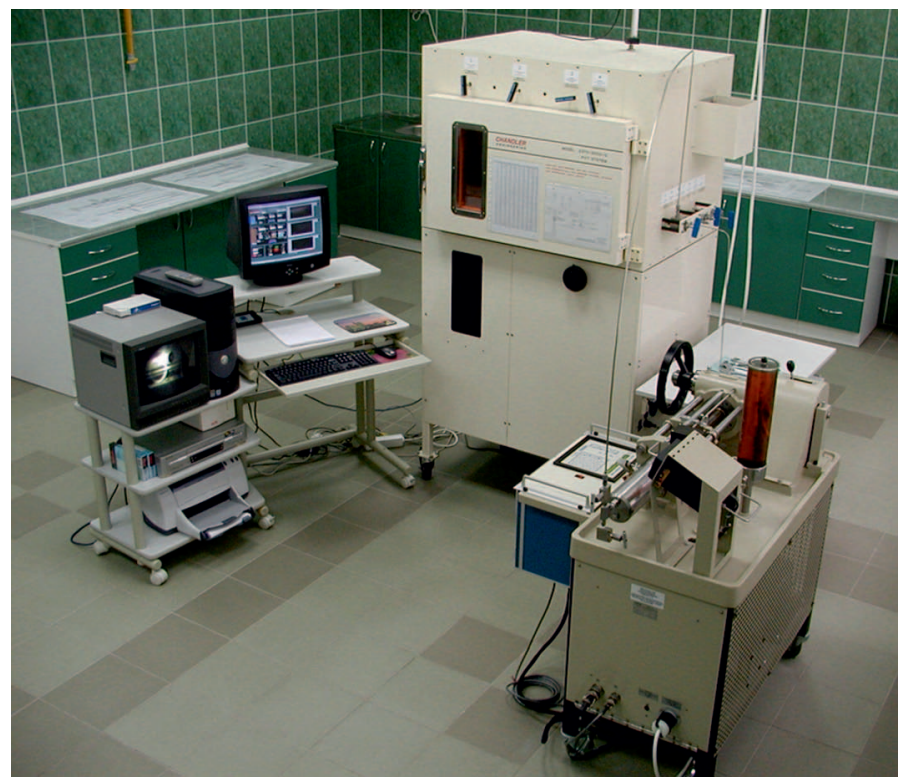

Rys. 2. Aparatura do badań PVT firmy Chandler Engineering Model 2370-3000-G PVT System (Lubaś et al., 2012; Szuflita i Kuśnierczyk, 2017; Szuflita et al., 2018)

Fig. 2. Chandler Engineering PVT apparatus - Model 2370-3000-G (Lubaś et al., 2012; Szuflita i Kuśnierczyk, 2017; Szuflita et al., 2018)

rozbudowany dodatkowo o szereg połączeń wysokociśnieniowych oraz ultratermostat służący do utrzymania zadanej temperatury (rys. 3). Takie podejście umożliwiało ogrzanie przepływającej próbki na odcinku pomiarowym, co jest głównym argumentem wykorzystania ultratermostatu w przeprowadzonych badaniach.
Głównym elementem aparatury, przy określaniu początkowych warunków ciśnienia i temperatury wytrącania parafiny, był wysokociśnieniowy filtr z zamontowanym filtrem membranowym o parametrach $0,8 \mu \mathrm{m}$ lub 2,7 $\mu \mathrm{m}$. Modernizacja aparatury polegała na połączeniu komory ciśnieniowej i pojemnika ciśnieniowego umieszczonych w łaźni termostatycznej aparatury PVT z układem filtrującym zanurzonym w oleju grzewczym ultratermostatu, który dodatkowo umożliwił precyzyjne utrzymanie stałej temperatury przepływającej próbki filtrowanej ropy. Jednocześnie w komorach badawczych aparatury PVT utrzymywano próbkę w temperaturze $40^{\circ} \mathrm{C}$ i pod ciśnieniem 20 bar przy uruchomionym mieszaniu ropy. Takie podejście wyeliminowało ryzyko wytrącenia osadu parafinowego w komorach ciśnieniowych, a tym samym popełnienie znaczących błędów przy określeniu jego ilości w warunkach pomiarowych. Następnie przez układ filtrujący przetłaczano badaną próbkę ropy / mieszaniny rop do uzyskania oporów przepływu wynoszących 0,5 bar (różnica ciśnienia przed i za filtrem). Po zakończeniu filtrowania przez układ filtrujący przetłaczano n-heptan celem usunięcia resztek ropy, tak by na powierzchni filtra pozostał jedynie odfiltrowany osad. Kolejnym krokiem było osuszenie filtra poprzez przedmuchanie azotem, po czym ochładzano filtr wraz z obudową do temperatury pokojowej i wyjmowano filtr. Ostatnim krokiem było ważenie filtra wraz z wychwyconym osadem.

Przed przystąpieniem do badań filtrowania rop - dla pozyskanych próbek wykonano analizy SARA. W tabeli 1

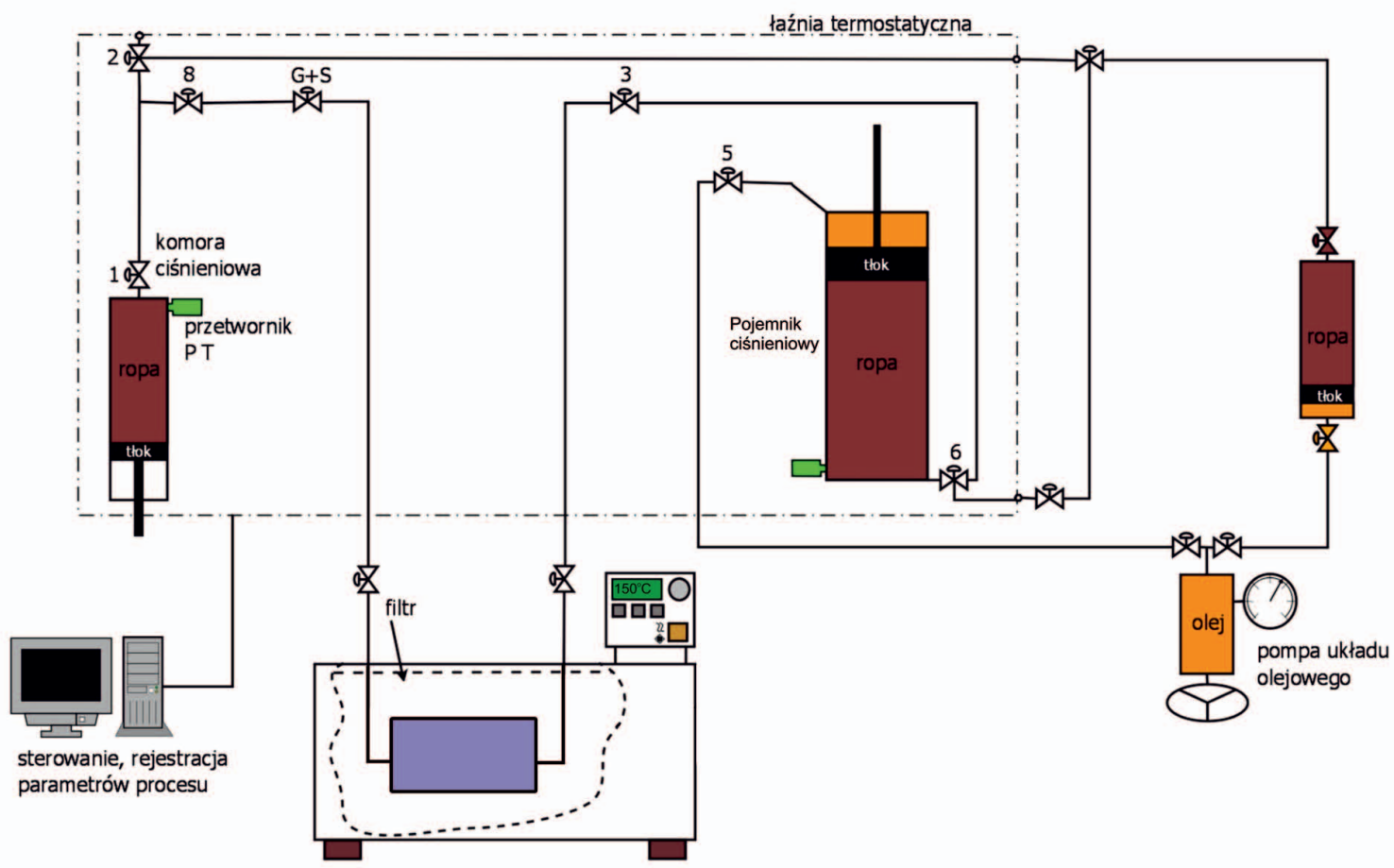

Rys. 3. Schemat aparatury PVT dostosowanej do badań kompatybilności rop metodą filtrowania

Fig. 3. PVT apparatus adapted to testing oil compatibility using the filtering method 
zestawiono zawartość podstawowych grup substancji tworzących ropę naftową, tj. składników węglowodorowych, żywic i asfaltenów. Przeprowadzona analiza pozwala na scharakteryzowanie następujących składników:

- węglowodory nasycone (saturated) - mieszanina węglowodorów parafinowych (n-alkanów), izoparafinowych (izo-alkanów) oraz naftenowych (cykloalkanów), również zawierających podstawniki alkilowe;

- węglowodory aromatyczne (aromatic) - mieszanina węglowodorów zawierających w cząsteczce jeden lub więcej pierścieni aromatycznych;

- żywice (resins) - silnie polarne związki zawierające w rdzeniu węglowodorowym atomy siarki, tlenu, azotu lub innych pierwiastków;

- asfalteny (asphaltenes) - wielkocząsteczkowe związki powstałe na skutek polimeryzacji i polikondensacji żywic.

\section{Wyniki badań}

Tabela 1. Charakterystyka badanych rop naftowych użytych do badań

Table 1. Properties of crude oils tested

\begin{tabular}{|l|c|c|c|}
\cline { 2 - 4 } \multicolumn{1}{l|}{} & Ropa A & Ropa B & Ropa C \\
\hline \hline Gęstość w $15^{\circ} \mathrm{C}\left[\mathrm{kg} / \mathrm{m}^{3}\right.$ ] & 870 & 825 & 891 \\
\hline $\begin{array}{l}\text { Zawartość węglowodorów } \\
\text { nasyconych }\end{array}$ & 25,8 & 35,0 & 44,0 \\
\hline Zawartość asfaltenów [\% mas.] & 2,1 & 0,2 & 1,2 \\
\hline $\begin{array}{l}\text { Zawartość węglowodorów } \\
\text { aromatycznych [\% mas.] }\end{array}$ & 26,2 & 12,6 & 24,1 \\
\hline Zawartość żywic [\% mas.] & 14,6 & 4,1 & 10,8 \\
\hline
\end{tabular}

\section{Wyniki filtrowania próbek ropy A $i$ ropy B} oraz ich mieszanin w temperaturze $20^{\circ} \mathrm{C} i 150^{\circ} \mathrm{C}$

- Dwie ropy naftowe: ropa A i ropa B.

- Trzy mieszanki w różnych proporcjach.

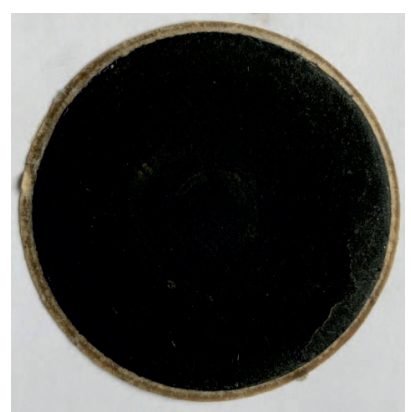

Rys. 4. Zdjęcie filtra $\mathrm{z}$ wychwyconym osadem dla jednej $\mathrm{z}$ mieszanin próbek ropy A i ropy $\mathrm{B} w$ temperaturze $20^{\circ} \mathrm{C}$

Fig. 4. Sediments caught by the filter from A and B oil samples and their blends at $20^{\circ} \mathrm{C}$
Tabela 2. Wyniki filtrowania ropy A i ropy B oraz ich mieszanin w temperaturze $20^{\circ} \mathrm{C}$

Table 2. Results of filtering of A and B oil samples and their blends at $20^{\circ} \mathrm{C}$

\begin{tabular}{|c|c|c|c|c|}
\hline \multicolumn{2}{|c|}{$\begin{array}{c}\text { Ropa } \\
{[\%]}\end{array}$} & $\begin{array}{c}\text { Objętość przefiltro- } \\
\text { wanej ropy } \boldsymbol{V}_{\text {ropy }}\end{array}$ & Masa osadu & $\begin{array}{c}\text { Ilość } \\
\text { osadu }\end{array}$ \\
\hline A & B & {$\left[\mathbf{c m}^{3}\right]$} & {$\left[\mathrm{g} / \mathbf{m}^{3}\right]$} & {$[\%]$} \\
\hline \hline 100 & 0 & 23,0 & 2392,1 & 0,274 \\
\hline 75 & 25 & 20,7 & 2743,9 & 0,320 \\
\hline 50 & 50 & 32,2 & 2550,0 & 0,302 \\
\hline 25 & 75 & 29,9 & 2085,9 & 0,252 \\
\hline 0 & 100 & 46,0 & 2013,2 & 0,247 \\
\hline
\end{tabular}

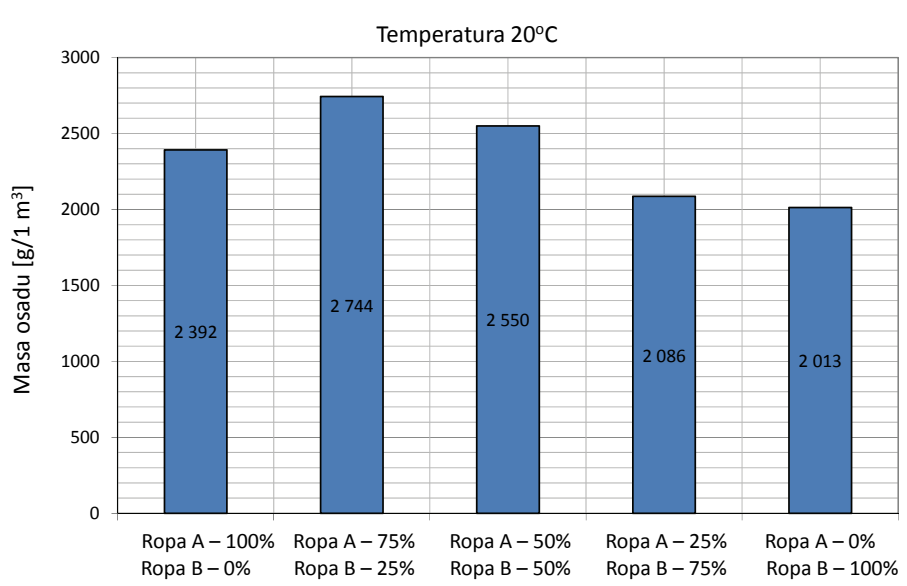

Rys. 5. Wpływ zmian zawartości ropy $\mathrm{B} w$ ropie A na ilość masy osadu wyrażoną $\mathrm{w} \mathrm{g} / \mathrm{m}^{3}$

Fig. 5. Impact of changes of oil samples B content in oil samples A on the amount of sludge mass expressed in $\mathrm{g} / \mathrm{m}^{3}$

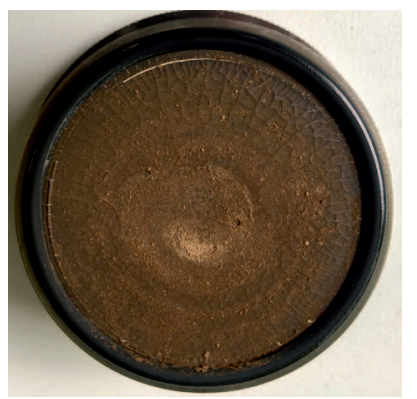

Rys. 6. Zdjęcie filtra z wychwyconym osadem dla jednej z mieszanin próbek ropy A i ropy B w temperaturze $150^{\circ} \mathrm{C}$

Fig. 6. Sediments caught by the filter from oil sample A and B and their blends at $150^{\circ} \mathrm{C}$

Tabela 3. Zestawienie wyników filtrowania w temperaturze $150^{\circ} \mathrm{C}$ rop A i B i ich mieszanin po $24 \mathrm{~h}$

Table 3. Summary of filtering results of A and B oil samples and their blends after $24 \mathrm{~h}$ at $150^{\circ} \mathrm{C}$

\begin{tabular}{|c|c|c|c|c|}
\hline \multicolumn{2}{|c|}{$\begin{array}{c}\text { Ropa } \\
{[\%]}\end{array}$} & $\begin{array}{c}\text { Objętość przefiltro- } \\
\text { wanej ropy } \boldsymbol{V}_{\text {ropy }}\end{array}$ & Masa osadu & $\begin{array}{c}\text { Ilośćc } \\
\text { osadu }\end{array}$ \\
\hline A & B & {$\left[\mathbf{c m}^{3}\right]$} & {$\left[\mathrm{g} / \mathbf{m}^{3}\right]$} & {$[\%]$} \\
\hline \hline 100 & 0 & 1,089 & 79,4 & 0,0091 \\
\hline 75 & 25 & 1,787 & 106,8 & 0,0525 \\
\hline 50 & 50 & 0,725 & 105,0 & 0,0306 \\
\hline 25 & 75 & 1,838 & 114,9 & 0,0188 \\
\hline 0 & 100 & 1,836 & 151,3 & 0,0186 \\
\hline
\end{tabular}




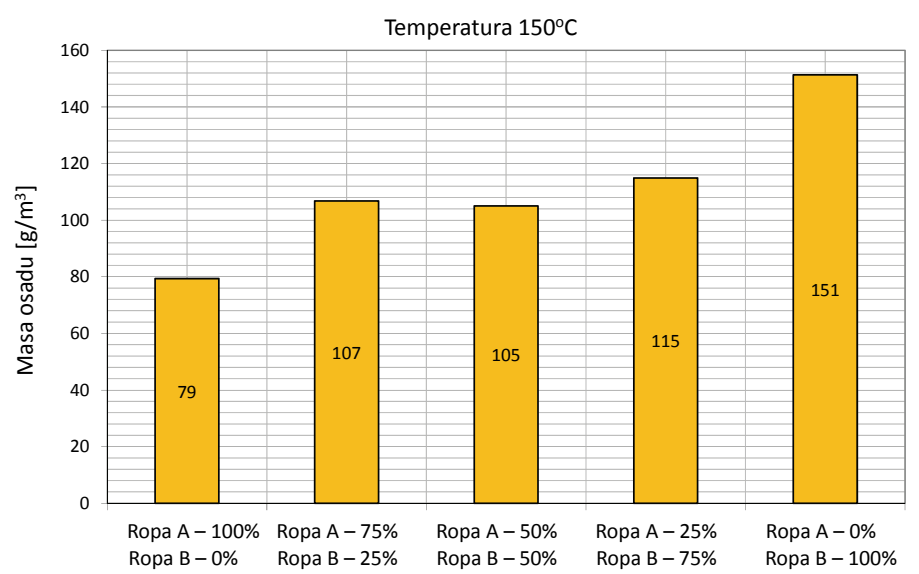

Rys. 7. Wpływ zmian zawartości ropy $B$ w ropie A na ilość masy osadu wyrażoną $\mathrm{w} \mathrm{g} / \mathrm{m}^{3}$

Fig. 7. Impact of changes of oil samples B content in oil samples A on the amount of sludge mass expressed in $\mathrm{g} / \mathrm{m}^{3}$ at $150^{\circ} \mathrm{C}$

\section{Wyniki filtrowania próbek ropy A i ropy C} oraz ich mieszanin w temperaturze $20^{\circ} \mathrm{C} i 150^{\circ} \mathrm{C}$

- Dwie ropy naftowe: ropa A i ropa C.

- Trzy mieszanki w różnych proporcjach.

Tabela 4. Podsumowanie wyników filtrowania rop A i C oraz ich mieszanin po $24 \mathrm{~h} \mathrm{w}$ temperaturze $20^{\circ} \mathrm{C}$

Table 4. Summary of filtering results of $\mathrm{A}$ and $\mathrm{C}$ oil samples and their blends after $24 \mathrm{~h}$ at $20^{\circ} \mathrm{C}$

\begin{tabular}{|c|c|c|c|c|}
\hline \multicolumn{2}{|c|}{$\begin{array}{c}\text { Ropa } \\
{[\%]}\end{array}$} & $\begin{array}{c}\text { Objętość przefiltro- } \\
\text { wanej ropy } \boldsymbol{V}_{\text {ropy }}\end{array}$ & Masa osadu & $\begin{array}{c}\text { Ilość } \\
\text { osadu }\end{array}$ \\
\hline A & C & {$\left[\mathbf{c m}^{3}\right]$} & {$\left[\mathbf{g} / \mathbf{m}^{3}\right]$} & {$[\%]$} \\
\hline \hline 100 & 0 & 68,8 & 719,2 & 0,083 \\
\hline 75 & 25 & 72,2 & 1098,0 & 0,126 \\
\hline 50 & 50 & 73,5 & 1108,3 & 0,126 \\
\hline 25 & 75 & 72,5 & 2370,6 & 0,268 \\
\hline 0 & 100 & 63,3 & 3483,7 & 0,392 \\
\hline
\end{tabular}

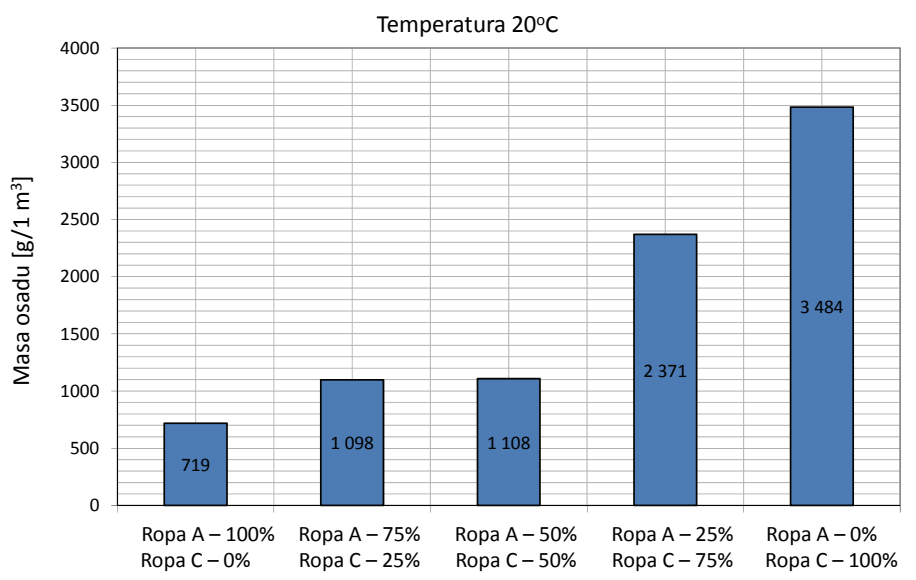

Rys. 8. Wpływ zmian zawartości ropy A w ropie C na ilość masy osadu wyrażoną $\mathrm{w} \mathrm{g} / \mathrm{m}^{3}$

Fig. 8. Impact of changes of oil samples B content in oil samples A on the amount of sludge mass expressed in $\mathrm{g} / \mathrm{m}^{3}$
Tabela 5. Podsumowanie wyników filtrowania rop A i C i ich mieszanin po $24 \mathrm{~h}$ w temperaturze $150^{\circ} \mathrm{C}$

Table 5. Summary of filtering results of $\mathrm{A}$ and $\mathrm{C}$ oil samples and their blends after $24 \mathrm{~h}$ at $150^{\circ} \mathrm{C}$

\begin{tabular}{|c|c|c|c|c|}
\hline \multicolumn{2}{|c|}{$\begin{array}{c}\text { Ropa } \\
{[\%]}\end{array}$} & $\begin{array}{c}\text { Objętość przefiltro- } \\
\text { wanej ropy } \boldsymbol{V}_{\text {ropy }}\end{array}$ & Masa osadu & $\begin{array}{c}\text { Ilość } \\
\text { osadu }\end{array}$ \\
\hline A & C & {$\left[\mathbf{c m}^{3}\right]$} & {$\left[\mathrm{g} / \mathbf{m}^{3}\right]$} & {$[\%]$} \\
\hline \hline 100 & 0 & 1104 & 85,6 & 0,0107 \\
\hline 75 & 25 & 1118 & 85,7 & 0,0106 \\
\hline 50 & 50 & 1106 & 90,4 & 0,0111 \\
\hline 25 & 75 & 1108 & 146,3 & 0,0179 \\
\hline 0 & 100 & 1010 & 221,9 & 0,0271 \\
\hline
\end{tabular}

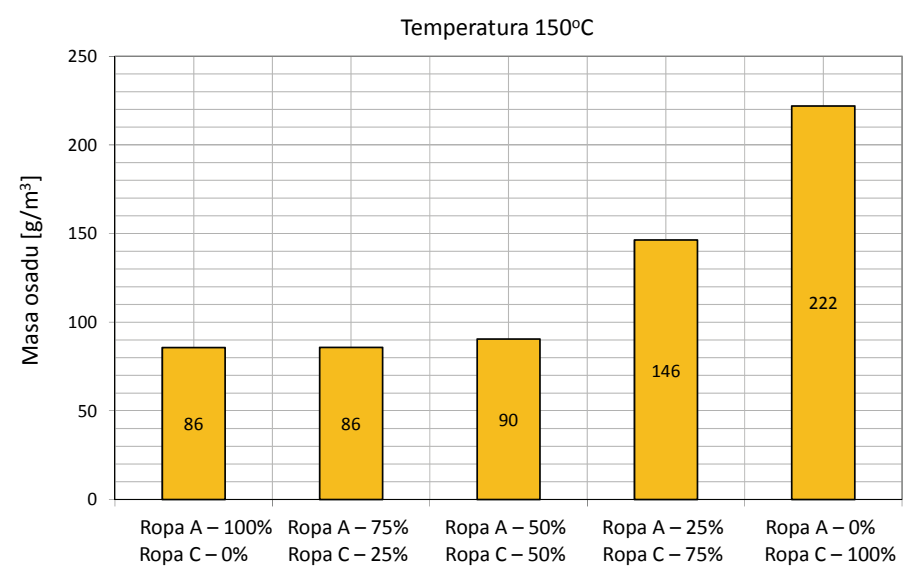

Rys. 9. Wpływ zmian zawartości ropy A w ropie C na ilość masy osadu wyrażoną $\mathrm{w} \mathrm{g} / \mathrm{m}^{3}$

Fig. 9. Impact of changes of oil samples B content in oil samples A on the amount of sludge mass expressed in $\mathrm{g} / \mathrm{m}^{3}$

\section{Podsumowanie}

Na podstawie przeprowadzonych pomiarów udało się wykazać brak kompatybilności próbki ropy A z B, lecz nie dla każdej mieszaniny. Okazuje się, że w temperaturze $20^{\circ} \mathrm{C}$ ropy są kompatybilne, pod warunkiem że udział ropy A w mieszaninie $\mathrm{z}$ ropą $\mathrm{B}$ nie przekroczy $25 \%$ (rys. 5). W temperaturze $150^{\circ} \mathrm{C}$ kompatybilność rop jest zachowana, gdy udział ropy A w mieszaninie nie przekroczy $50 \%$ (rys. 7).

Próbki ropy A i ropy $\mathrm{C}$ oraz ich mieszanin można określić jako kompatybilne - nie wykazano większej ilości osadu, niżby to wynikało z określonej ilości osadów stałych przy filtrowaniu czystych próbek. Można się nawet pokusić o stwierdzenie, że ich zmieszanie powoduje redukcję osadów, w przypadku gdy udział ropy A w mieszaninie z ropą $\mathrm{C}$ nie przekroczy $50 \%$ (rys. 8 i 9).

Aby uzyskać dokładniejsze wartości dopuszczalnych udziałów procentowych w badanych mieszaninach, należałoby wykonać pomiary dla większej liczby próbek, np. w krokach co $10 \%$. Minusem takiego rozwiązania jest konieczność pozyskania 
kilkudziesięciu litrów ropy i wydłużenia czasu niezbędnego do wykonania pomiarów.

Brak specjalistycznej aparatury dostępnej na rynku umożliwiającej wykonanie pomiarów filtrowania z uwzględnieniem parametrów ciśnienia i temperatury wymusił przystosowanie posiadanej aparatury PVT do wyżej opisanych badań. Opracowana metodyka przewiduje użycie specjalnie do tego celu skonstruowanego układu filtrującego, przez który przetłaczana jest próbka ropy. Wykorzystane zostało doświadczenie zdobyte przy realizacji poprzednich prac, na podstawie których złożono wnioski patentowe na dwa nowe sposoby badań. Dzięki takiemu podejściu Zakład Badania Złóż Ropy i Gazu do swojej oferty badawczej może dopisać kolejny rodzaj/typ badań, który może wykonać z dużą powtarzalnością i dokładnością.

Artykuł powstał na podstawie pracy statutowej pt.: Wptyw kompatybilności rop na depozycję osadów w tańcuchu dystrybucji ropy naftowej - praca INiG - PIB na zlecenie MNiSW; nr zlecenia: 0032/KB/2019, nr archiwalny: DK-4100-0032/2019.

\section{Literatura}

Asomaning S., Watkinson A.P., 2000. Petroleum stability and heteroatom species effects in fouling of heat exchangers by asphaltenes. Heat Transfer Engineering, 21(3): 10-16. DOI: 10.1080/014576300270852.

Carbognani L., Orea M., Fonseca M., 1999. Complex nature of separated solid phases from crude oils. Energy and Fuels, 13(2), 351-358. DOI: $10.1021 / \mathrm{ef} 9801975$.

Goual L., Firoozabadi A., 2002. Measuring asphaltenes and resins, and dipole moment in petroleum fluids. AIChE Journal, 48(11): 2646-2663. DOI: 10.1002/aic.690481124.

Guzmán R., Ancheyta J., Trejo F., Rodríguez S., 2017. Methods for determining asphaltene stability in crude oils. Fuel, 188: 530-543. DOI: 10.1016/j.fuel.2016.10.012.

Hirschberg A., DeJong L.N.J., Schipper B.A., Meijer J.G., 1984. Influence of Temperature and Pressure on Asphaltene Flocculation. Society of Petroleum Engineers Journal, 24(3): 283-293. DOI: 10.2118/11202-PA.

Lubaś J., Biały E., Warnecki M., 2012. Asfalteny w problematyce wydobycia ropy naftowej. Prace Naukowe Instytutu Nafty $i$ Gazu, 179

Painter P., Veytsman B., Youtcheff J., 2015. Guide to asphaltene solubility. Energy and Fuels, 29(5): 2951-2961. DOI: 10.1021/ef502918t.

Pfeiffer J.P., Saal R.N.J., 1940. Asphaltic bitumen as colloid system. Journal of Physical Chemistry, 44(2): 139-149. DOI: 10.1021/ j150398a001.

Rogel E., Carbognani L., 2003. Density estimation of asphaltenese using molecular dynamics simulations. Energy and Fuels, 17(2): 378-386. DOI: $10.1021 / \mathrm{ef020200r.}$

Sepúlveda J.A., Bonilla J.P., Medina Y., 2010. Prediction for Asphaltenes Using SARA Analysis for Pure Petroleum. Revista Ingeniería, 7: $103-110$

Stankiewicz A., Flannery M.D., Fuex N.A., Broze J.G., Coach J.L., Dubey S.T., Ratulowski J., 2002. Prediction of Asphaltene Deposition Risk in E\&P Operations. Petroleum phase behavior and fouling; held in conjunction with the AIChE 2002 Spring national meeting: 410-416. ISBN: 0816997748.

Szuflita S., Kuśnierczyk J., 2017. Badanie wpływu ciśnienia i temperatury na proces wytrącania parafin w ropie naftowej. Nafta-Gaz, 6: 395-404. DOI: 10.18668/NG.2017.06.04.

Szuflita S., Kuśnierczyk J., Wojnicki M., Warnecki M., 2018. Badania laboratoryjne określające wzrost potencjału parafinowania wraz ze spadkiem temperatury. Nafta-Gaz, 10: 759-767. DOI: 10.18668/ ng.2018.10.08.

Wang J., Buckley J.S., 2003. Asphaltene Stability in Crude Oil and Aromatic Solvents - The Influence of Oil Composition. Energy and Fuels, 17(6): 1445-1451. DOI: 10.1021/ef030030y.

Warnecki M., 2011. Doskonalenie techniki badań warunków flokulacji asfaltenów metodą prześwietlania ropy strumieniem światła podczerwonego. Nafta-Gaz, 7: 454-462.

Wiehe I.A., 2008. Process chemistry of petroleum macromolecules. CRC Press.

Wiehe I.A., Kennedy R.J., 2000. The Oil Compatibility Model and Crude Oil Incompatibility. Energy \& Fuels, 14: 56-59.

Wiehe I.A., Kennedy R.J., Dickakian G., 2001. Fouling of nearly incompatible oils. Energy \& Fuels, 15(5): 1057-1058. DOI: 10.1021/ ef010063i.

\section{Akty prawne i dokumenty normatywne}

ASTM D4740-19 Standard Test Method for Cleanliness and Compatibility of Residual Fuels by Spot Test.

ASTM D5186-19 Standard Test Method for Determination of the Aromatic Content and Polynuclear Aromatic Content of Diesel Fuels By Supercritical Fluid Chromatography.

ASTM D7112-19 Standard Test Method for Determining Stability and Compatibility of Heavy Fuel Oils and Crude Oils by Heavy Fuel Oil Stability Analyzer (Optical Detection).
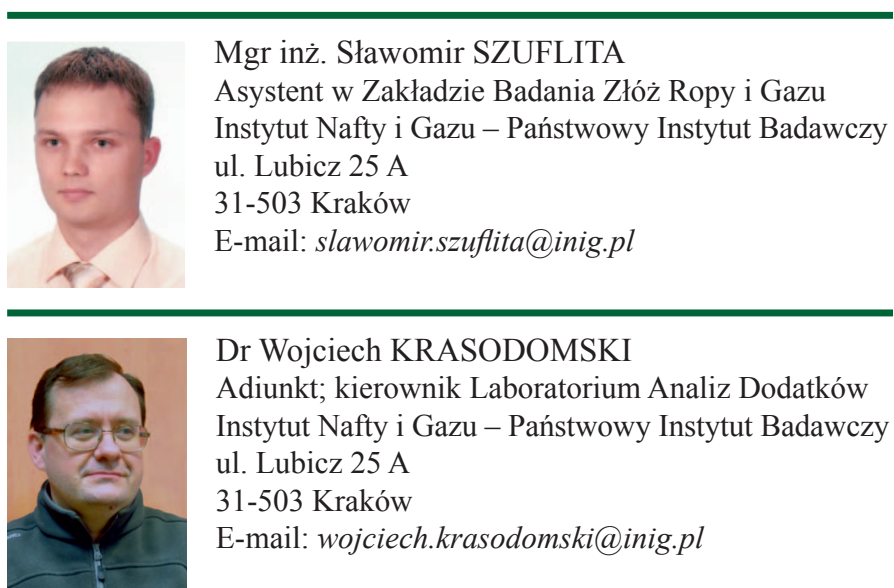

Dr Wojciech KRASODOMSKI

Adiunkt; kierownik Laboratorium Analiz Dodatków Instytut Nafty i Gazu - Państwowy Instytut Badawczy ul. Lubicz 25 A

31-503 Kraków

E-mail: wojciech.krasodomski@inig.pl

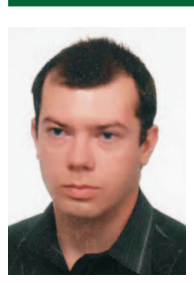

Mgr inż. Jerzy KUŚNIERCZYK

Specjalista badawczo-techniczny w Zakładzie

Badania Złóż Ropy i Gazu

Instytut Nafty i Gazu - Państwowy Instytut Badawczy ul. Lubicz 25 A

31-503 Kraków

E-mail: jerzy.kusnierczyk@inig.pl

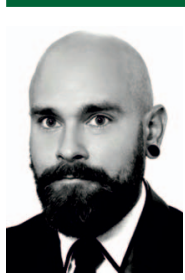

Mgr inż. Mirosław WOJNICKI

Asystent w Zakładzie Badania Złóż Ropy i Gazu Instytut Nafty i Gazu - Państwowy Instytut Badawczy ul. Lubicz $25 \mathrm{~A}$

31-503 Kraków

E-mail: miroslaw.wojnicki@inig.pl

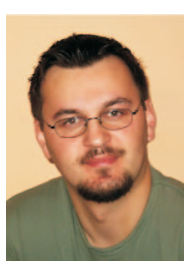

Dr inż. Marcin WARNECKI

Kierownik Zakładu Badania Złóż Ropy i Gazu Instytut Nafty i Gazu - Państwowy Instytut Badawczy ul. Lubicz $25 \mathrm{~A}$

31-503 Kraków

E-mail: marcin.warnecki@inig.pl 